\title{
Substantiation of investment component of development of property potential of economic systems in agricultural sector of economy
}

\author{
Kunitsky Konstantin ${ }^{1}$ \\ ${ }^{1} \mathrm{PhD}$ student , Kyiv National University of Construction and Architecture, \\ Kyiv, Ukraine \\ Abstract. The article is devoted to the development of factor analysis tools based on the DuPont model, which \\ are adapted to the realities of management of domestic (Ukrainian) agrarian enterprises in the context of \\ substantiation of directions of effective use of their property potential. It is revealed on the basis of economic \\ models of formation of property potential of the tendency of investment-innovative development of agricultural
} enterprises.

Key words: property potential, classification, assessment, development, system of indices, management system, reproduction, use efficiency.

\section{Introduction}

Dynamic transformation processes in Ukraine require the use of a perfect mechanism for managing the financial resources advanced in the assets of the economic potential of the economic systems of the agricultural sector. Property potential management is one of the major problems of any business entity's functioning. The formation and efficient use of property potential assets is an essential means of ensuring the enterprise's competitiveness, profitability, and overall sustainable development in the future. In addition, reliable estimation of the volume of objects of the property potential of the enterprise makes it possible to substantiate the real market value of the entity, to determine the price of the enterprise in the market and its participation in the formation of national wealth.

The main purpose of the article is : - to structure the object composition of the property potential of agricultural enterprises, as well as to deepen theoretical studies on the mechanisms of its formation and use in economic activity; - identify, on the basis of economic models, the formation of the property potential of the tendency of investment and innovative development of economic entities;- to substantiate the level of utilization of the objects of the enterprise property potential based on the development of the adapted DuPont model and the involvement of factor analysis tools to determine their impact on the business activity of the enterprises.

\section{The results}

Explanation of the main research material. The optimum process of formation and use of property ensures the effective functioning of the enterprise as a whole, modern technological equipment of the economy, increase of objects of activity in size and range, creation of profit, increase of productivity of personnel, formation of investmentinnovative cash flows. Under the influence of external and internal factors, property objects of the enterprise are constantly in dynamics and development, which results in the increase of property potential and in the whole of the national wealth of rural territories and the state. The study of the genesis of the essence of the definitions of "potential" and "property" allowed us to suggest the definition of "property potential of the enterprise". Property potential of the enterprise - set of opportunities of property objects, which are controlled by the enterprise as a result of past events, function in tangible, intangible, financial forms and, using them systematically in economic activity, the enterprise expects to receive economic benefits, including synergetic effect, in the future in the form net income, value added, net income and equity.

Based on the study, systematization and generalization of existing views in the economic literature on property and types of potential, the thesis substantiates the classification of property potential, which includes 19 classification features, in particular in the geographical sector, specialization (in accordance with types of economic activity in areas of economic management) forms, legal regime, forms of ownership, forms of management, economic responsibility, size of economic entities, results, formation, sources formed quality, cost, enterprise valuation, facility valuation, degree of liquidity, time horizon (management stages), facility characteristics, business processes and information support. 
It is proved that the objects of property potential of the enterprise have a direct influence on the effective use of labor, management, production, investment and other types of potentials of the enterprise. At the same time, these potentials, in turn, create the preconditions for the functioning of property potential objects. This reflects the synergistic property of all components of the property potential of the enterprise, the result of which is manifested in the implementation of the mission of the enterprise through obtaining socio-economic effect. In turn, property potential is an integral part of the system of economic potential, which is formed by directions of resource potential, economic and value potentials.

The development of property potential should be characterized by innovative processes, without which it is impossible. Studies have shown that to ensure investment-innovative development of property potential, it is necessary to use three types of strategies for innovative development of the enterprise: transfer, borrowing and building up. The strategy of transfer is to use elements of foreign scientific and technical potential in the economic activity of domestic enterprises. The most striking example of this strategy being used by Ukrainian agricultural companies is the introduction of modern No-till farming technology, which has been actively used in the United States for a long time. The borrowing strategy involves the development of production of high-tech products from other countries based on the use of their own labor potential and the existing scientific and technical base of agricultural enterprises. The basis of the strategy of increasing the property potential of agricultural enterprises can be the training of highly qualified personnel in the system of higher education institutions of the Ministry of Agrarian Policy of Ukraine for master's programs, the intensification of renovation of property objects on an innovative basis and the development of agricultural advisory services. We believe that investment and innovation development of property potential is ensured by the economic process, as a result of which the company updates its own property objects by investing investment resources in attracting innovation, and also actively modifies intellectual capital.

The tendencies of development of objects of property potential of agricultural enterprises in the regional aspect are analyzed by volume of formation and condition of objects of property potential, as well as by structure and sources of formation. The analysis made it possible to conclude that the management system needs to optimize the value of property objects per unit of finished goods. The main objective of the business is to attract a minimum amount of advanced capital for the formation of property and to obtain maximum financial results. To optimize the amount of financial resources advanced to the property per unit of finished products, simulation tools have been used to determine the absolute change in the magnitudes of interdependent economic indicators, which will make it possible to predict their status and development in the future.

Analysis of the value of property by the potential of agricultural enterprises can not be done without an effective system of information support. Information about the property potential of the company is contained in the planned, regulatory, actual and forecast indicators. It is revealed that the main disadvantages that characterize the existing approaches to the selection of indicators for valuation of enterprise property are: a large total number of indicators for property valuation; ambiguous interpretation of indicators with the same economic content, which complicates the analysis process; the lack of a unified approach to the formation of methodology for the calculation of indicators in the economic literature and regulations; lack of a system of indicators to evaluate the assets of the enterprise.

DuPont Analysis (also known as the dupont identity, DuPont equation, DuPont Model or the DuPont method) is an expression which breaks ROI (return on investment) into three parts. The name comes from the DuPont Corporation that started using this formula in the 1920s. DuPont explosives salesman Donaldson Brown invented this formula in an internal efficiency report in 1912. Calculation (formula):

ROE $_{(\text {DuPont formula })}=($ Net profit $/$ Revenue $) *($ Revenue $/$ Total assets $) *($ Total assets $/$ Equity $)=$ Net profit margin $*$ Asset Turnover * Financial leverage.

DuPont model tells that ROE is affected by three things:

* Operating efficiency, which is measured by net profit margin;

* Asset use efficiency, which is measured by total asset turnover;

* Financial leverage, which is measured by the equity multiplier;

If ROE is unsatisfactory, the DuPont analysis helps locate the part of the business that is underperforming.

ROE $=($ Profit margin $) *($ Asset turnover $) *($ Equity multiplier $)=($ Net profit/Sales $) *($ Sales/Average Total Assets $) *($ Average Total Assets/Average Equity $)=($ Net Profit/Equity) Or Profit/Sales $*$ Sales/Assets=Profit/Assets $*$ Assets/Equity Or $\mathrm{ROS} * \mathrm{AT}=\mathrm{ROA} *$ Leverage $=\mathrm{ROE}$

* Profitability (measured by profit margin)

* Asset efficiency (measured by asset turnover)

* Financial leverage (measured by equity multiplier)

The DuPont identity breaks down ROI (that is, the returns that investors receive from the firm) into three distinct elements. This analysis enables the analyst to understand the source of superior (or inferior) return by comparison with 
companies in similar industries (or between industries). The DuPont identity is less useful for industries such as investment banking, in which the underlying elements are not meaningful. Variations of the Du Pont identity have been developed for industries where the elements are weakly meaningful. The return on assets (ROA) ratio developed by DuPont for its own use is now used by many firms to evaluate how effectively assets are used. It measures the combined effects of profit margins and asset turnover.

\section{Conclusions}

Toolkit of the system of management of property potential of agricultural enterprises is generalized and disclosed; main sources of reproduction of property potential are systematized, problems and prospects of their use are investigated; the level of utilization of property potential of enterprises is determined on the basis of the adapted DuPont model and tools of factor analysis of influence of property potential on the volumes of business activity of enterprises.

\section{References}

[1] Phillips, Matt (2015). "The DuPont invention that changed how things work in the corporate world". Quartz (publication).

[2] Tetyana Marchuk, Dmytro Ryzhakov, Galyna Ryzhakova and Sergiy Stetsenko (2017). Identification of the basic elements of the innovationanalytical platform for energy efficiency in project financing. Investment Management and Financial Innovations (open-access), 14(4), 12-20. doi:http://10.21511/imfi.14(4).2017.02

[3] Sorokina, L.V., Goiko, A.F., Stetsenko, S.P., Izmailova, K.V. (2017) Ekonometrychnyy instrumentariy upravlinnya finansovoyu bezpekoyu pidpryyemstv budivnytstva [Econometric tools for financial security management of construction companies], Kyiv. KNUBA. [in Ukrainian].

[4] Ryzhakova, Galyna, Malykhina, Oksana, Ryzhakov, Dmytro (2018). Risk-management in the system of management of integration processes as a component of modernization of Ukrainian economy. Management of Development of Complex Systems, 36, $113-119$.

[5] Ryzhakova, Galyna, Prykhodko, Dmitry (2017). Models of target selection of representative indicators of activities of construction enterprises: the etymology and typology of systems of diagnostics. Management of Development of Complex Systems, 32, 159-165. 